\title{
Technologies of ground support monitoring in block caving operations
}

T Dawn Canary Systems Inc., USA

\begin{abstract}
Block caving operations are increasing in popularity in the mining industry as companies are looking to extract large, deep orebodies faster and more economically. Underground mass mining methods, such as block caving, present several geotechnical hazards and risks that must be monitored using technology. Advances in geotechnical instrumentation have helped bring value to the operational and safety risks associated with block caving. There are two types of instrumentation, internal and external, that must be used in conjunction with one another to effectively monitor the geotechnical risks and ground support of the block cave. Internal monitoring of pore pressure, stress, deformation, load, and cave propagation will provide insight into the internal stability of the rock mass as well as provide leading indicators of potential failures. Key internal instrumentation would include Multipoint Borehole Extensometers (MPBX), in-place inclinometers (IPI), time-domain reflectometry (TDR), seismic monitoring, open borehole cameras, Networked Smart Markers, instrumented rock and cable bolts, embedment strain gauges, borehole and New Australian Tunnelling Method (NATM) pressure cells, borehole stressmeters, and piezometers. To corroborate the internal deformation and stress information, external instrumentation should be utilised to monitor the surface deformation within the underground workings as well as on the topographic surface. External instrumentation includes tape extensometers, laser distance sensors, prisms, crackmeters, LiDAR laser scanners, and satellite interferometric synthetic aperture radar (InSAR). When using these multiple instrumentation technologies together, one can have a better understanding of the mining-induced ground response, have more transparency in monitoring and handling risk, numerical model calibration, and ensure that the cave is operating at the highest level of safety and production levels.
\end{abstract}

Keywords: ground support, block caving, instrumentation, monitoring

\section{Introduction}

Block caving is a hard rock underground mining method that allows large, low-grade deposits to be mined with relativity low operating costs. The method involves undercutting the orebody, allowing the rock mass to collapse due to gravity into a series of funnels from where the ore will then be extracted from drawpoints. The operational risks associated with block caving, must be monitored with the use of instrumentation to ensure safety to personnel and underground infrastructure. Geotechnical risks include mud rushes, induced stress redistribution, induced seismic activity, airblasts, and surface subsidence. These risks can be monitored using a systematic approach utilising instrumentation that analyses internal stresses and deformation that then can be corroborated using instruments that monitor the visual, external deformation. The information collected from the instrumentation can then be used to verify ground support design, understand how the cave is reacting to mining, and be the first line defence against potential failures.

\section{Internal instrumentation monitoring}

It is important to have internal instrumentation installed prior to and during the undercutting the block cave. As the induced abutment stress is redistributed, particularly to the production level (Laubscher 2003), the internal rock mass can exhibit signs of deformation that is crucial to monitor. There are six main types of internal monitoring that will help shed light onto the inherent geotechnical risks and required ground support 
for the block cave; deformation, cave propagation, stress, strain, load, and pore pressure. All types can be automatically monitored to provide real-time data acquisition.

\subsection{Instruments for measuring internal deformation and cave propagation}

As the induced stress in the cave beings to be redistributed, the internal rock mass experiences deformation as a response. This internal deformation can be quantified using instrumentation specifically made for this purpose. Another important aspect of block caving is understanding the cave shape and propagation as mining and undercutting are occurring. It is important that these factors are understood to ensure safety of personnel and that the geotechnical risks associated are being properly monitored. This next section will explore the different types of displacement and cave monitoring instrumentation available on the market today. Table 1 depicts each instrument type that will be discussed with in the next section along with the advantages and disadvantages of each.

Table 1 Advantages and disadvantages instrumentation to monitor internal deformation

\begin{tabular}{|c|c|c|}
\hline Instrument type & Advantages & Disadvantages \\
\hline $\begin{array}{l}\text { Borehole } \\
\text { extensometers. }\end{array}$ & $\begin{array}{l}\text { Internal structure deformation. } \\
\text { Internal strain capture. } \\
\text { Inexpensive unit cost. } \\
\text { Manual or remote monitoring. } \\
\text { Adjustable rods dependent on project } \\
\text { requirements. }\end{array}$ & $\begin{array}{l}\text { Limited range of measurement. } \\
\text { Displacement calculated on an assumed } \\
\text { fixed point, typically the downhole anchor. } \\
\text { If the downhole anchor is not truly fixed, } \\
\text { the displacement is relative. }\end{array}$ \\
\hline $\begin{array}{l}\text { In-place } \\
\text { inclinometers. }\end{array}$ & $\begin{array}{l}\text { Internal structural deformation. } \\
\text { Identifies internal failure zones. } \\
\text { Easy installation. } \\
\text { System is robust, stable, and reliable } \\
\text { long-term. }\end{array}$ & $\begin{array}{l}\text { Expensive unit cost per area monitored. } \\
\text { Expensive installation cost. } \\
\text { Lateral displacements assume the bottom } \\
\text { of the casing is fixed. If the bottom casing } \\
\text { is not truly fixed, displacement is relative. } \\
\text { Measurements discontinued in case of } \\
\text { shearing due to large displacements. }\end{array}$ \\
\hline $\begin{array}{l}\text { Time-domain } \\
\text { reflectometry. }\end{array}$ & $\begin{array}{l}\text { Remote monitoring. } \\
\text { Internal structural deformation. } \\
\text { Cave back monitoring. }\end{array}$ & $\begin{array}{l}\text { Expensive unit cost per area monitored. } \\
\text { Expensive installation cost. } \\
\text { Apparent deformation. } \\
\text { Can be sheared prior to cave back due to } \\
\text { ground movement. }\end{array}$ \\
\hline $\begin{array}{l}\text { Seismic } \\
\text { monitoring. }\end{array}$ & $\begin{array}{l}\text { Detect lateral and depth variations. } \\
\text { Produce detailed images of structural } \\
\text { features. } \\
\text { Cave evolution monitoring. }\end{array}$ & $\begin{array}{l}\text { Amount of data collected is vast. } \\
\text { Data reduction and processing are time } \\
\text { consuming. } \\
\text { No direct displacement or stress } \\
\text { measurement. } \\
\text { Empirical interpretation. }\end{array}$ \\
\hline $\begin{array}{l}\text { Borehole } \\
\text { cameras. }\end{array}$ & $\begin{array}{l}\text { Enables capture of cave back and } \\
\text { muck pile. }\end{array}$ & $\begin{array}{l}\text { Tend to get stuck in boreholes. } \\
\text { Expensive unit cost per area monitored. } \\
\text { Manual interpretation. }\end{array}$ \\
\hline $\begin{array}{l}\text { Cave tracker } \\
\text { system. }\end{array}$ & $\begin{array}{l}\text { Real-time cave flow monitoring. } \\
\text { Wireless and robust. }\end{array}$ & Expensive installation cost. \\
\hline $\begin{array}{l}\text { Networked smart } \\
\text { markers. }\end{array}$ & $\begin{array}{l}\text { Real-time cave back monitoring. } \\
\text { Robust. } \\
\text { Unaffected by ground movement in a } \\
\text { range of a few metres. }\end{array}$ & Expensive installation cost. \\
\hline
\end{tabular}




\subsubsection{Borehole extensometers: multiple anchors}

Borehole extensometers are used to measure the stability, movement, and behaviour of the surround rock mass. Borehole extensometers with multiple anchors (MPBX) have become one of the most widely used instruments in underground mining operations as they provide valuable insight into rock deformation.

MPBXs can have multiple nodes, also known as anchors that are installed along the MPBX body. The displacement of each node is calculated by comparing the current measurement to the initial measurement. Movement is then referenced to the instrument head which is installed at the collar or toe of the borehole in stable ground. The resulting displacement can then be used to determine rate, acceleration of movement, and strain within the rock mass.

It is recommended that MPBXs be installed in areas where movement is predicted to occur, fixed facilities that are considered high traffic areas, and evenly distributed across the footprint. It is standard to have a ring of MPBXs installed at each point of interest, with one located in the back and one installed in each rib. This will allow the engineers to capture the abutment stress prior to and during undercutting. Since the anchors in the MPBXs are installed in the borehole at specific lengths, the engineers monitoring the data will be able to model displacement versus depth and load distribution.

\subsubsection{In-place inclinometers}

In-place inclinometers (IPI) allow for long-term monitoring of deformation. The term in-place refers to the inclinometers being typically installed in an inclinometer casing within a borehole, which can then be read automatically with the use of a datalogger. Some types of IPI's, such as Shape Accelerometer Arrays (Measurand 2019) allow installation in a grouted pipe or can be directly grouted in place.

IPI's should be installed in areas that lateral ground movements are anticipated, specifically around and above underground openings (Geokon 2019a). This instrumentation can be a leading indicator that more ground support is required and can be the first line of defence against potential failures.

\subsubsection{Time-domain reflectometry}

Time-domain reflectometry (TDR) is widely used in the mining industry to measure fault displacements and rock deformation. The operating principle of TDR can be viewed as a real-time sensing electrical measurement technique in which a voltage pulse is emitted and then reflected by any kind of deformation along the coaxial cable. The resolution of the cable depends on how long the installed coaxial cable is, along with how many points are used, however it is typical to use 0.5 or one-metre resolution to monitor the cave back. The distance to the detected deformation is proportional to the time between the initial voltage pulse and the arrival of the returned pulse. It is important to note that TDR monitor does not provide absolute movement data, and the reflection coefficient is a relative measure of the signal reflection. However, continuous observation of the TDR reflections can provide indication of continued or stabilised deformation.

The waveform signature of the TDR can then be graphed, which defines the type of cable deformation. TDR Waveforms are a resultant of reflections that are measured and presented as a function of time, the time is translated to depth based on the known propagation velocity of the coaxial cable being utilised. Data returned is known as the reflection coefficient, or percentage of reflection, and is in a range of 1 (open circuit) to -1 (short circuit), and zero indicates no reflection. Figure 1 depicts a single TDR installed in the cave back showing active cable breaks overtime, where depth refers to distance down hole. The instance where the waveform diverts from zero towards 1 , is the apparent depth down hole where the coaxial cable is in an open circuit, signalling the end of the cable at the cave front. In this example, the TDR waveform is collected once a day, and only active cable breaks are presented. 
TDR Cable Breaks

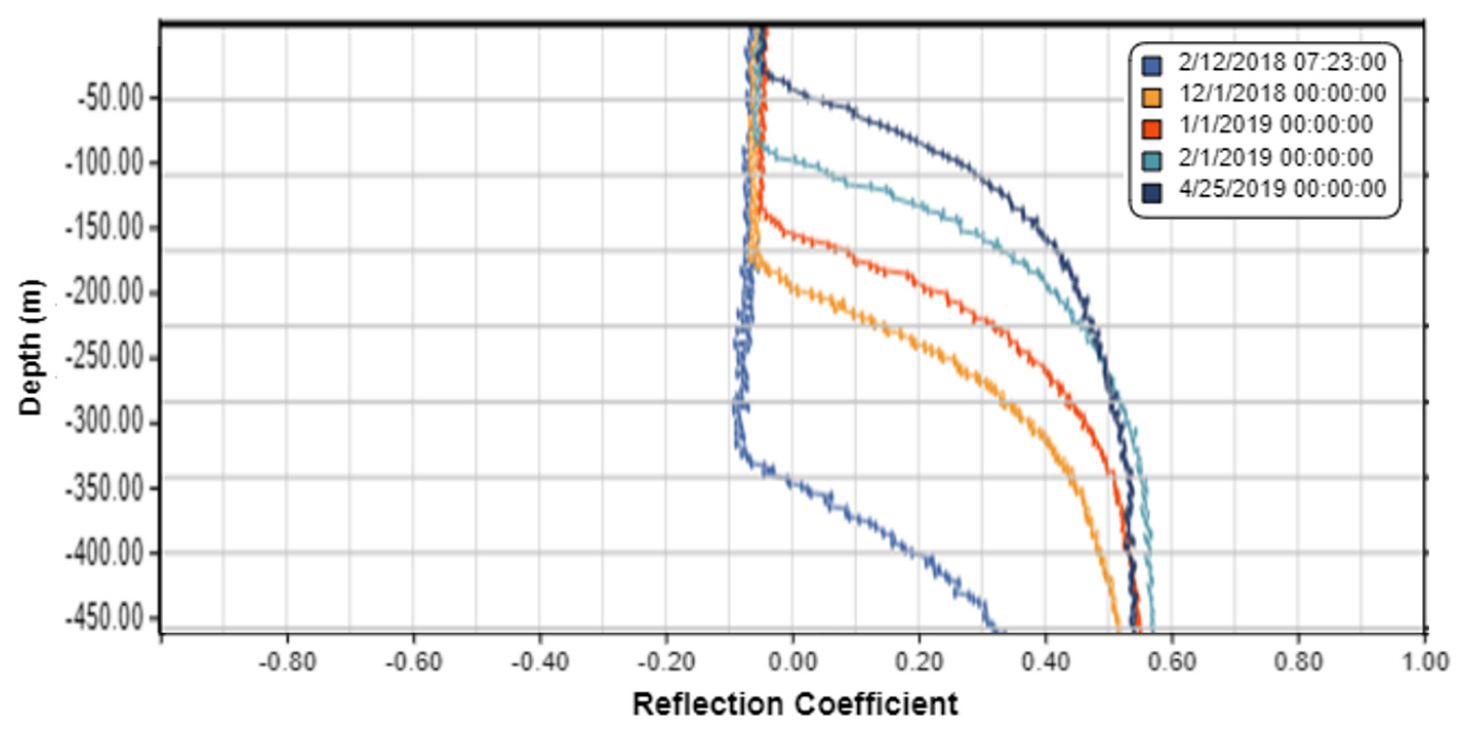

Figure 1 A TDR cable installed in the back of a cave showing active cable breaks over time, inferring cave propagation

TDR cables can be used to identify cave initiation and propagation as well as monitoring the effect the caving has on the surrounding rock mass. TDR cables should be installed from above, along sides and below the anticipated caving zone. The length of the TDR cable can then be calculated from the waveform, which will allow a 3-D shape to be created of the cave front, and will shed light into the horizontal and vertical propagation. By understanding the shape of the cave front, the production rate can be adjusted in specific areas to increase or slow down the cave rate (La Rosa \& Chen 1997).

\subsubsection{Seismic monitoring}

Seismic monitoring in block caving operations has become widely used as it gives insight into the entire cave volume rather than at single points along the cave back. Monitoring seismic events can be accomplished by using triaxial or uniaxial accelerometers and geophones. Both types of instrumentation measure the vibrations from seismic events that can be tracked in real time in 3-D space.

The seismic monitoring system needs to be designed in such a way that all seismic records be collected to at least a Richter magnitude of -2.0 (Hudyma et al. 2008). Each mine will have a different requirement based on the size of the cave and the amount of sensors required, however it is important that events greater than or equal to the minimum moment magnitude can be captured within the site specified location accuracy. As mining occurs and the cave progresses, it is expected that some of the installed seismic monitoring devices will be lost and will need to be replaced to keep a full seismic record.

The following is an example of a seismic system design at the Northparkes mine that utilises accelerometers and geophones to capture the seismic activity under the production level. Hudyma et al. (2008) recommends installing two uniaxial accelerometers in 50 to 100 metre length holes alongside the production level. One accelerometer should be installed at the toe of the borehole and the other should be in the middle to have better location accuracy of events (Hudyma et al. 2008). Low frequency geophones are optimised to capture larger magnitude seismicity, and should be utilised to accurately location larger events than may occur outside of the main microseismic array. It is typical to have a single low frequency geophone located away from the active mining area; however multiple sensors that are deployed in a triangular array allow for optimal detection (ESG Solutions 2019). 
The seismic events can be viewed in 3D space as shown in Figure 2.

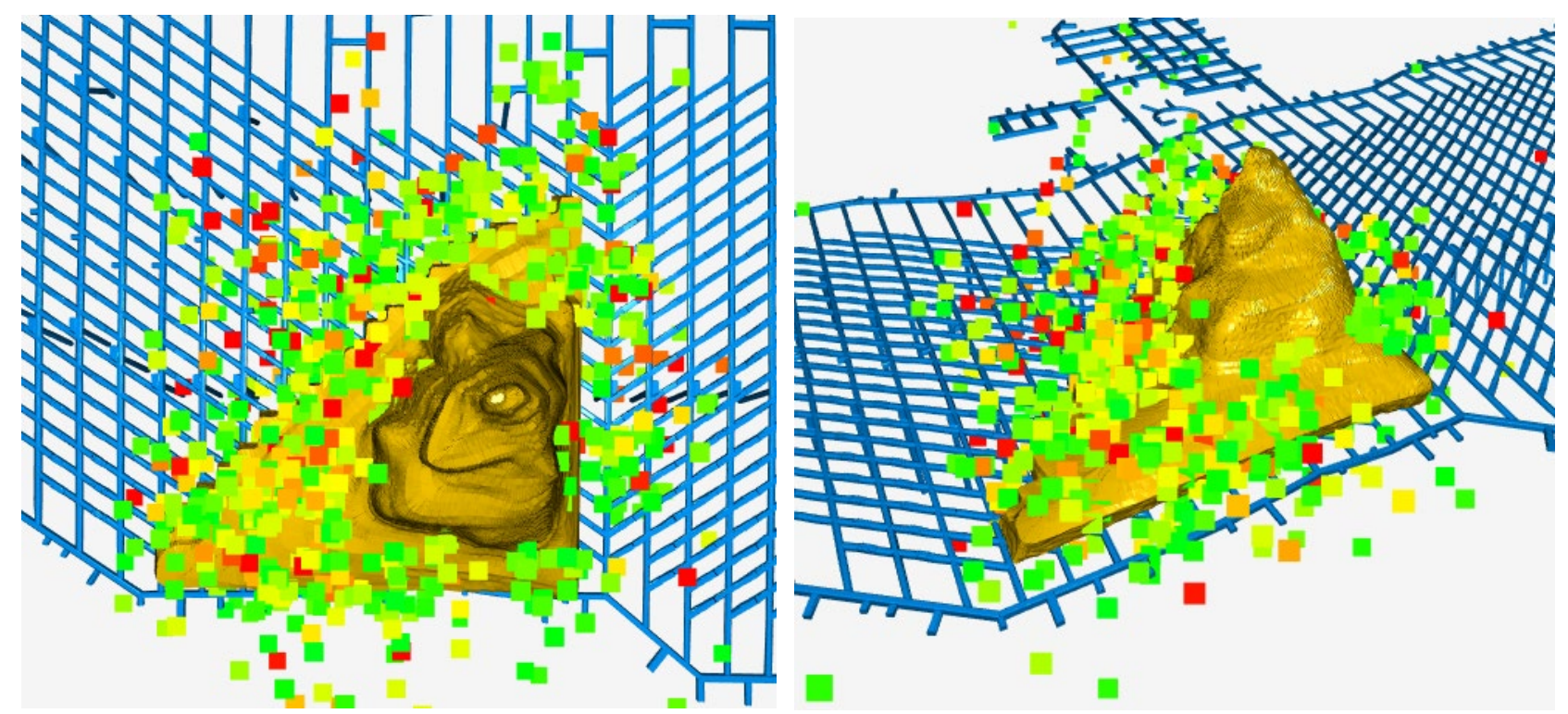

Figure 2 Microseismic events over moment magnitude 0.7

\subsubsection{Borehole cameras}

One of the major concerns in block caving are air blasts that are a result of a "plunger effect" from a rapid collapse of rock into a void or muck pile (Laubscher 2003). The air from the gap is pushed out through any opening or the muck pile and can have serious implications to personnel safety and equipment.

Monitoring the airgap can be captured manually by using borehole cameras. If using a borehole camera, it is important that a downhole survey is completed as necessary depending on the cave propagation rate. When completing a survey with a borehole camera, it is important to note the following conditions:

- The condition of the borehole walls.

- The current cave back depth.

- The depth to the muck pile.

- The movement of the muck pile.

The positioning of the open hole in relation to the cave is crucial for successful monitoring of the cave back and muck pile. The number of open holes required is site specific, however it is necessary to have at least one open hole situated above the cave initiation. Depending on the size and shape of the orebody, more open holes may be required to adequately track the cave back progression and the distance to the muck pile.

\subsubsection{Cave Tracker system}

The Cave Tracker ${ }^{\mathrm{TM}}$ system works by installing a series of beacons that are embedded within the orebody and detectors that are installed within the surrounding rock mass (Elexon Mining 2016a). The beacons contain a strong magnet that will spin at desired intervals and the magnetic field produced is then captured by the detector, allowing for accurate 3D coordinates of the beacon (Elexon Mining 2016a). As the data is collected, engineers and operators gain insight to the cave flow, the cave propagation, and inferring any air gaps that may be forming. It is important that the data collected from the Cave Tracker ${ }^{\mathrm{TM}}$ system is corroborated with other monitoring techniques such as TDR or borehole camera surveys for airgap monitoring. 


\subsubsection{Networked Smart Markers}

The principal behind Networked Smart Markers is like TDR cables, in that they are used to monitor the cave back and cave propagation overtime. Networked Smart Markers use radio frequency to communicate with neighbouring markers and the signal of the radio strength is recorded (Elexon Mining 2016b). The strength of the radio signal is directly related to the distance between the Smart Markers and as the signal weakens over time, it indicates that the markers are moving farther apart (Elexon Mining 2016b). The cave back can then be depicted in 3D space and changes in the cave back can be monitored over time. Networked Smart Markers have an advantage over TDR cables in the way they can provide relational position data, even after a significant fragmentation within the rock mass. The Elexon Smart Marker data can be viewed in real time as shown in Figure 3. The green indicates that the Smart Markers have good radio signal between one another, while the red depicts where communication has been lost.

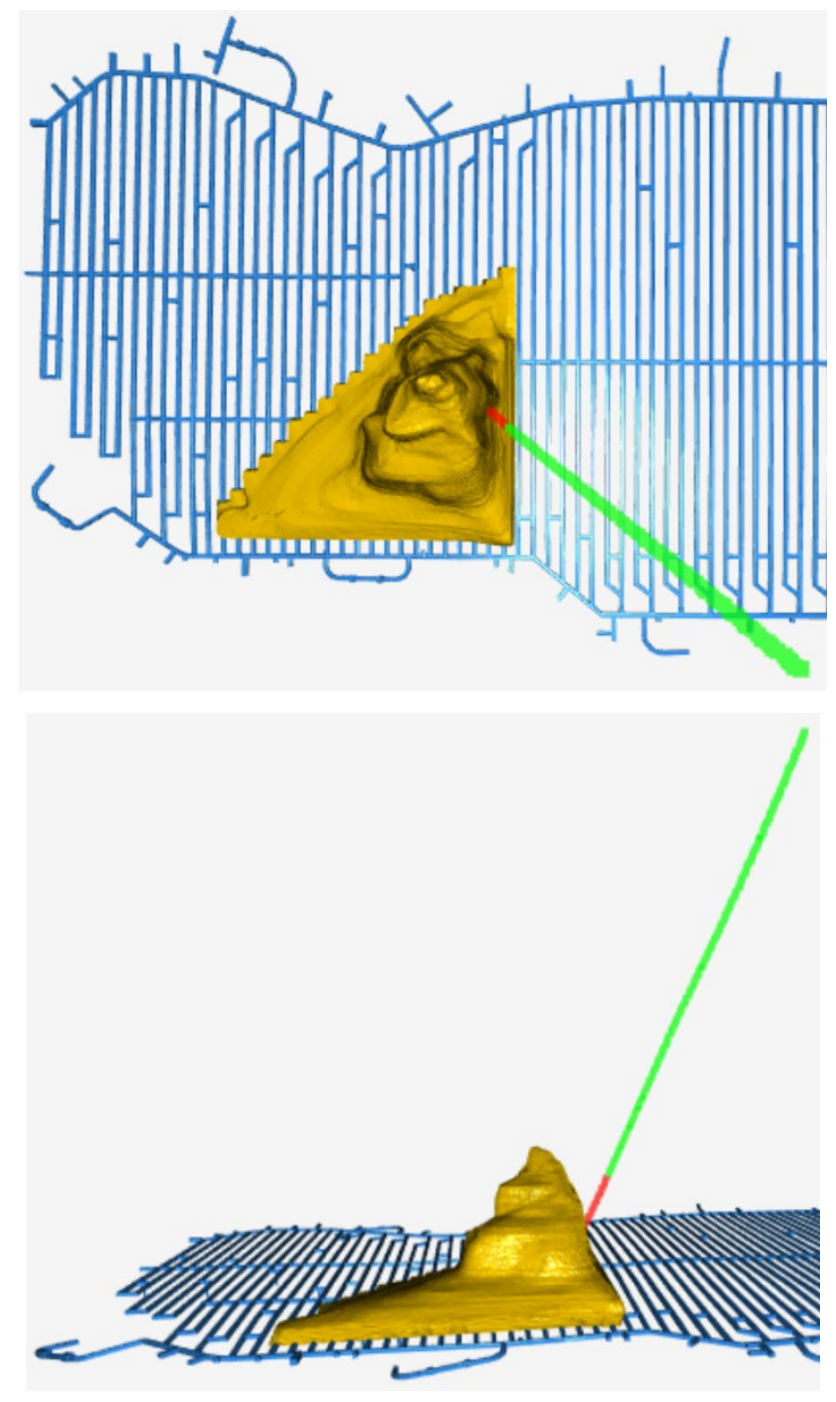

Figure 3 Example Elexon Smart Markers viewed in 3D space showing where communication has been lost

\subsection{Instruments for measuring stress, strain, and load}

As with many block caving operations, there will always be high abutment stress due to undercutting. It is important to characterise these stresses prior to and during the undercutting sequence. Understanding the redistribution of stress will give insight to the proper ground support measures that are needed. Table 2 depicts each instrument type that will be discussed with in the next section along with the advantages and disadvantages of each. 
Table 2 Advantages and disadvantages instrumentation to monitor internal stress, strain, and load

\begin{tabular}{|c|c|c|}
\hline Instrument type & Advantages & Disadvantages \\
\hline Instrumented rockbolts. & $\begin{array}{l}\text { Installed the same as non- } \\
\text { instrumented rockbolts. } \\
\text { Give validation to rockbolt design. } \\
\text { Used to calibrate stress models. }\end{array}$ & $\begin{array}{l}\text { Surface preparation required. } \\
\text { Vibrating wire is fragile. } \\
\text { Reaction plates must be } \\
\text { perpendicular to bolt for accuracy. }\end{array}$ \\
\hline Instrumented cable bolts. & $\begin{array}{l}\text { Internal structure deformation. } \\
\text { Internal strain capture. } \\
\text { Internal load capture. } \\
\text { Inexpensive unit cost. } \\
\text { Manual or remote monitoring. } \\
\text { Adjustable rods dependent on } \\
\text { project requirements. }\end{array}$ & $\begin{array}{l}\text { Limited range of measurement. } \\
\text { Displacement calculated on an } \\
\text { assumed fixed point, typically the } \\
\text { downhole anchor. If the downhole } \\
\text { anchor is not truly fixed, the } \\
\text { displacement is relative. }\end{array}$ \\
\hline Embedment strain gauges. & $\begin{array}{l}\text { Easy to install. } \\
\text { Inexpensive unit cost. } \\
\text { Used to calibrate stress models. }\end{array}$ & $\begin{array}{l}\text { Fragile. } \\
\text { Must be installed during construction. }\end{array}$ \\
\hline Borehole pressure cells. & $\begin{array}{l}\text { Captures stress changes within } \\
\text { the rock mass. }\end{array}$ & $\begin{array}{l}\text { Must be installed in specific } \\
\text { orientations. } \\
\text { Difficult to install. }\end{array}$ \\
\hline $\begin{array}{l}\text { New Australian Tunnelling } \\
\text { Method (NATM) pressure } \\
\text { cells. }\end{array}$ & Characterises dynamic loading. & $\begin{array}{l}\text { Difficult to ensure encapsulation in } \\
\text { certain concrete and horizontal } \\
\text { orientations. } \\
\text { Extensive cable protection. } \\
\text { Installed during construction. }\end{array}$ \\
\hline Borehole stressmeters. & $\begin{array}{l}\text { Captures point loading. } \\
\text { Long-term stress state } \\
\text { monitoring. }\end{array}$ & $\begin{array}{l}\text { Must be installed in specific } \\
\text { orientations. } \\
\text { Difficult to install. } \\
\text { Indicated stress magnitude can only } \\
\text { be approximated. }\end{array}$ \\
\hline
\end{tabular}

\subsubsection{Instrumented rockbolts}

Rockbolts are a ubiquitous ground support mechanism used in underground mines. They are used to reinforce unstable exterior rocks to more stable interior rock by inserting a steel rod with a mechanical or chemical anchor situated at one end. The rockbolts are then tensioned after installation to provide more support to the surrounding rock mass.

There are currently two types of instrumented rockbolts that are being produced, one is instrumented with a vibrating wire strain gauge and the other with a load cell. Both types of rockbolts are ideal in measuring the distribution of bolt loads that will help in determining the overall design of the ground support. Due to the importance of rockbolts in the primary support of the underground workings, it is important to verify that the rockbolt is functioning properly, and that excess load is not being experienced (Mitri 2013, p. 136). Instrumented rockbolts should be installed in the undercut and production levels where the ground response will constantly change due to the induced abutment stress. 


\subsubsection{Instrumented cable bolts}

Cable bolts are used for rock reinforcement as a part of the ground support design in most underground mining operations. Instrumented cable bolts combine the support capabilities of a standard seven-strand cable bolt with a six-wire extensometer (Mine Design Technologies 2019).

Like an MPBX, the extensometer nodes are at predetermined lengths. As the cable bolt is stretched, the strain between the anchor points can be calculated (Mine Design Technologies 2019). After the strain between the node points are calculated, the load profile can then be inferred based on the cable-rock-grout interface properties (Mine Design Technologies 2019).

Instrumented cable bolts allow for engineers to verify the ground support design and to understand the strain and loading that is occurring in the area. Like the instrumented rockbolts, cable bolts should be installed in the undercut and production levels to accurately capture induced stress redistribution.

\subsubsection{Embedment strain gauges}

Embedment strain gauges are a great tool to monitor the shotcrete and convergence within the drift. These strain gauges are specifically designed to be embedded in concrete, either directly onto the rebar or mesh, or directly into a borehole that is grouted with concrete (Geokon 2018). As the tension in the wire changes, the resonant frequency of the wire will change and will be recorded with a datalogger.

Embedment strain gauges can help bring value into understanding the strains and loads that are being applied along the drift. It is important to have these gauges installed on the back and ribs to have a better understanding of the stresses being applied and to corroborate that ground support design.

\subsubsection{Borehole pressure cells}

Borehole pressure cells are specifically designed to monitor stress changes within the rock mass. The design of the cell consists of two steel plates welded together at the edges and the space in between filled with hydraulic oil. The cell needs to be grouted into a borehole and pressurised to the in situ stress level plus $10 \%$ after the grout has hardened (Geokon 2019b). As the stress in the rock mass changes, the hydraulic pressure in the cell will change which is then recorded in the pressure gauge or pressure transducer.

It is important to note that borehole pressure cells mainly react to stress changes that are perpendicular to the cell (Geokon 2019b). If stress needs to be monitoring in two directions, then two or three borehole pressure cells will need to be installed in different orientations, either in the same borehole or in adjacent boreholes (Geokon 2019b).

\subsubsection{New Australian Tunnelling Method pressure cells}

The NATM calls for shotcrete to be applied to newly exposed rock to preserve the inherent strength of the ground. It is thought that shotcrete applied rapidly will enable the tunnel or opening to be self-supporting, minimising the need for additional support. NATM pressure cells are installed in the shotcrete lining to capture the radial and tangential pressures exerted along the drift (Geokon 2012). As pressure is applied to the pressure cell, the fluid will compress, changing the resonant vibrating frequency, which can then be measured by a datalogger.

It is important to note that the pressure cell will need to be re-pressurised via a hydraulic oil filled pinch tube after the shotcrete or concrete has cured. During the curing process, the temperature of the concrete will rise, causing the pressure cell to expand. The concrete will then begin to cool, which causes the cell to contract leaving a void between the cell and the concrete. The cell must be in full contact with the concrete, if not the pressures exerted will not be captured by the pressure cell.

The NATM pressure cells should be used to validate the shotcrete lining by measuring the amount of support pressure that the shotcrete has introduced. When coupled with convergence monitoring methods, an assessment can be made of the thickness of the lining. By understanding the radial and tangential pressures 
being applied, the amount of shotcrete needed for support an area can be modified. By doing so, the NATM pressure cell gives value to monitoring the performance of the shotcrete lining that can ultimately lead to reductions in tunnel support costs.

\subsubsection{Borehole stressmeters}

Borehole stressmeters, uniaxial and biaxial, utilise a vibrating wire transducer to measure the changing stress within the rock mass. The change in the diameter of the gauge is directly proportional to the change in the stress in the rock.

There are many variables that play a role in the calibration of the uniaxial stressmeter, such as the prestress applied during installation as well as the orientation of the stressmeter. "Due to this, the accuracy of the data collected is largely indeterminate and the indicated stress magnitude of the rock mass can only be approximated" (Geokon 2019c). Because the stressmeter is a uniaxial device, to completely capture the stresses in any given plane, three stressmeters must be installed at $0^{\circ}, 45^{\circ}$, and $90^{\circ}$ orientations (Geokon 2019c).

Biaxial stressmeters are designed to be directly installed in the material that is to be monitored or grouted into a borehole. Three or six sensors are orientated perpendicular to the plane of installation at $60^{\circ}$ intervals (Geokon 2019d). The advantages of using a biaxial stressmeter is the measurements allow for a $360^{\circ}$ profile of the load acting on the instrument to be derived.

Stressmeters should be used for long-term stress state monitoring in the rock mass to provide insight as the undercut transitions across the footprint and as the cave propagates towards the surface. They are also a good indicator of any point loaded that is occurring in a specific area.

\subsection{Piezometers for measuring pore pressure}

Groundwater and the associated pore pressure can lead to negative effects on the stability of the surrounding rock mass. The introduction of pore pressure leads to a reduction in the effective stress, which in turn reduces the shear strength of the rock mass (Morton et al. 2008, p.226). The most effective way to understand pore pressure is by measuring the hydraulic head at any given point, typically represented in feet or metres of water present by using a piezometer. Once the hydraulic head and water flow is understood, the necessary ground support can be determined, and any potential mud rush events can be properly monitored. Table 3 depicts the advantages and disadvantages of piezometers.

Table 3 Advantages and disadvantages peizometers

\begin{tabular}{lll}
\hline Instrument type & Advantages & Disadvantages \\
\hline Piezometers. & Measures internal & Difficult to profile entire hydraulic column. \\
& hydraulic pressures. & No deformation measurement. \\
& Captures depressurisation. & Expensive installation cost. \\
\hline
\end{tabular}

Piezometers are one of the most common geotechnical instruments used in the mining industry today. They are versatile, robust, and bring value in understanding the internal pore pressure. Before installing piezometers, it is essential to note the surrounding geology, geotechnical structures, and current groundwater elevation. The type of piezometer used depends on these factors and should be aligned in such a way that the pore pressure and water elevation can be modelled and incorporated into the geotechnical design (Morton et al. 2008). Figure 4 shows a hydrograph displaying the pressure in metres of water. 


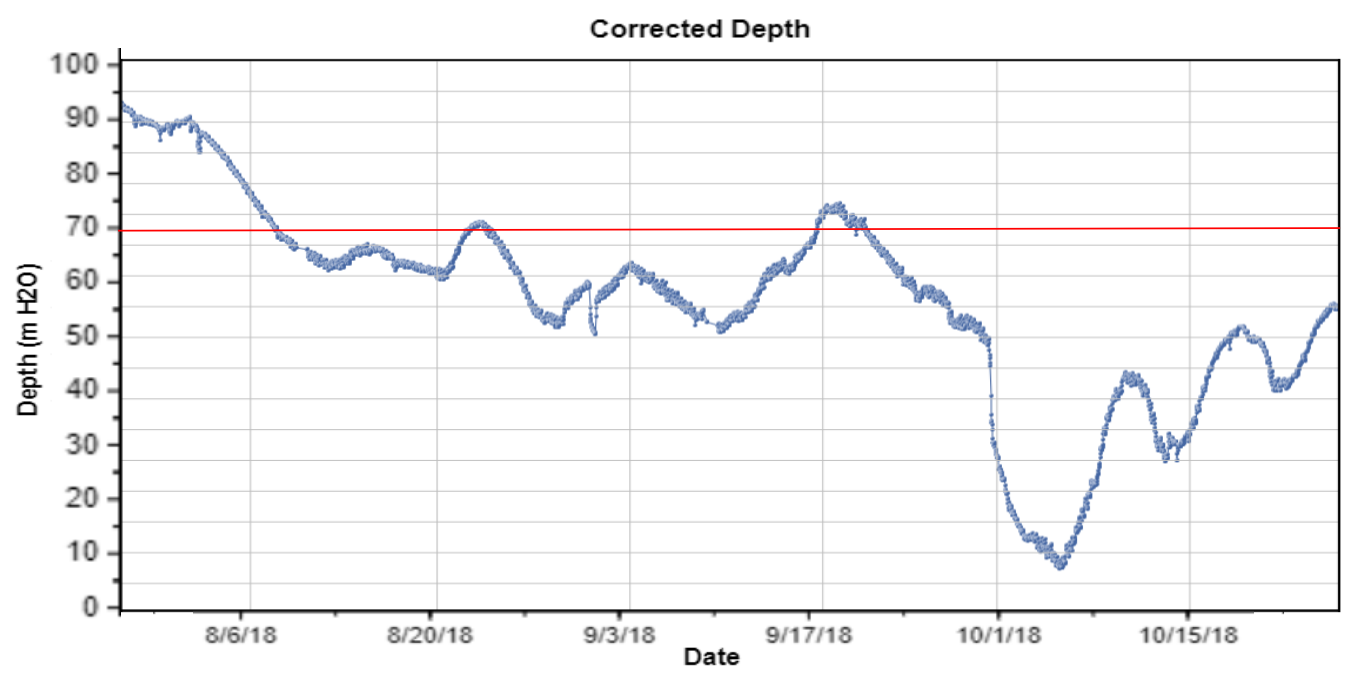

Figure 4 Hydrograph represented in metres of water with alarming threshold

A Vibrating Wire (VM) piezometer works by converting the hydraulic pressures into a frequency that can then be recorded. As the water pressure changes, the diaphragm will deflect which in turn changes the wire tension and resonant frequency of the vibration. The coil and magnet are used to pluck the wire and sense the resultant vibration frequency. This resultant frequency of the induced signal is then transmitted and recorded using a datalogger.

During production, one of the biggest geotechnical risk factors in block caves is mud rushes. A mud rush is defined as a sudden inflow of mud from a drawpoint or other underground openings into the mine (Butcher et al. 2005). Mud rushes occur when there is a sudden loss of shear strength, which is due to an increase in the water present and the associated increase in pore pressure (Vallejos et al. 2017). It is important that water is properly pumped from the underground workings to help mitigate the risk of a mud rush and the hydraulic pressure is measured with the use of a piezometer.

\section{External instrumentation monitoring}

As the induced stress in the rock mass is redistributed and as material is being mined, there will be signs of deformation that is visible externally on the ribs, back, and floor. External instrumentation can monitor these displacements and corroborate the internal stresses recorded from the internal instrumentation.

Deformation on the surface can sometimes be seen with the naked eye, however it is important to monitor these displacements with instrumentation that can be automated. There are a wide variety of instruments available on the market, some of which monitor point displacements, while other give a broader picture of deformation occurring over time. One of the most common types of deformation is called convergence. Convergence is the reduction in the surface area of a void due to stress redistribution around the excavation surface. Convergence can occur due to localised mechanical deformation, stress redistribution, and changes in the pore pressure of the rock mass. The rate at which convergence happens will decrease until an equilibrium level is obtained. Table 4 depicts each instrument type that will be discussed with in the next section along with the advantages and disadvantages of each. 
Table 4 Advantages and disadvantages instrumentation to monitor external deformation

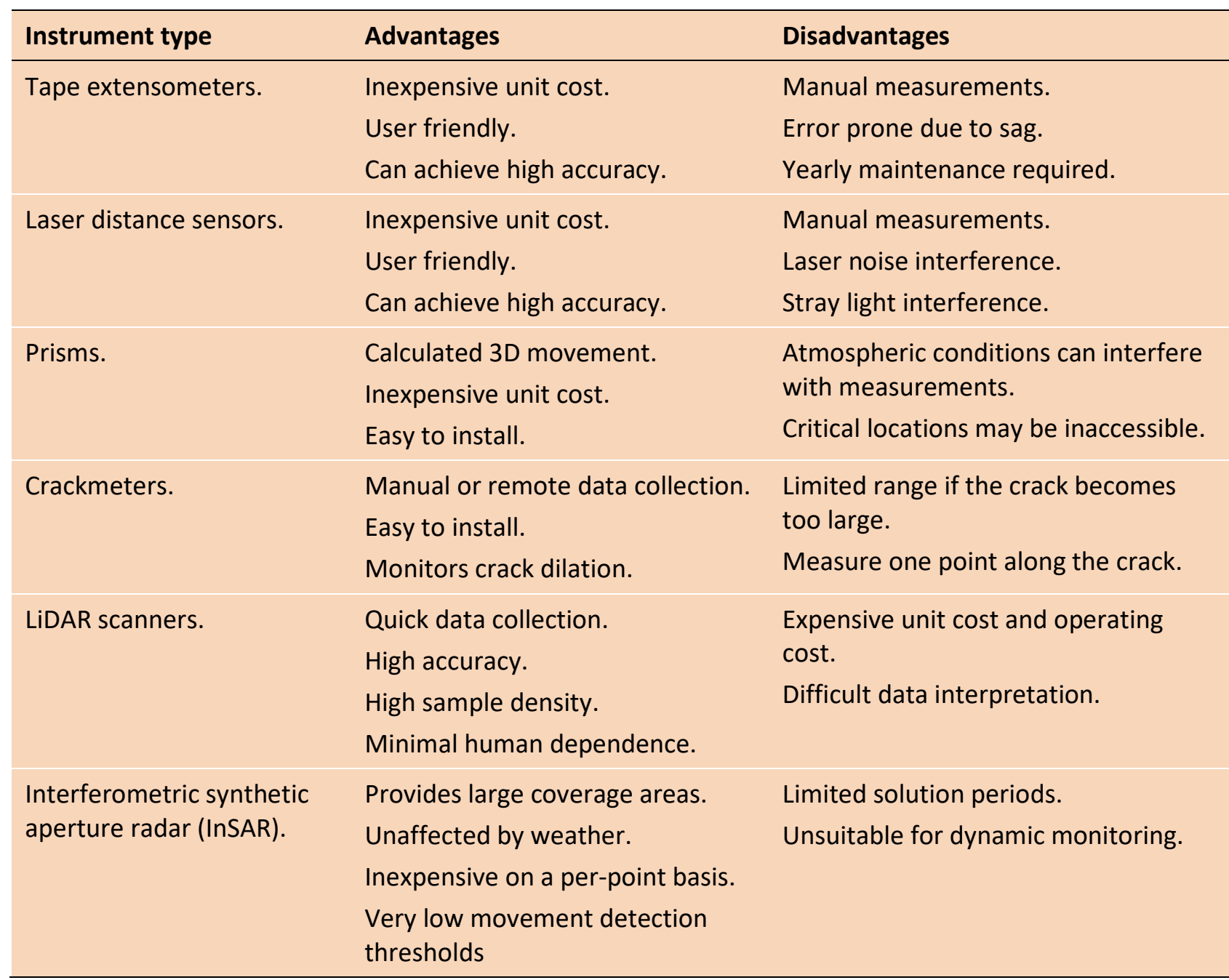

\subsection{Tape extensometers and laser distance sensors}

Tape extensometers and laser distance sensors are commonly used to measure drift deformation and convergence rate. It is important to note that both types of instrumentation are manually recorded and cannot be automated.

Tape extensometers measure the changes in the distance separating two fixed points along the drift. In most cases, anchor points are located on either side of the drift and the measurements taken account for the closure of the tunnel walls due to convergence. The convergence between the back and floor can also be measured using a tape extensometer.

Laser distance sensors use phase shift comparison to accurately gauge the distance to a reflective target. Typically, reflective targets are installed along the drift and at critical points to measure convergence.

It is important that anchor points or reflective targets are established at regular intervals to gain a better understanding on the convergence within the area.

\subsection{Prisms}

Prisms or monitoring points have been used in the underground mining industry for many years to survey drifts. They can also be used to monitor subsidence of the block cave on the surface. In underground applications, prisms are shot using a survey team and a theodolite, while on the surface the prisms can be 
read using an automated total station. Both ways measure the angles and distances to the prisms, which then allows for the 3D movement of the prism to be calculated.

For underground applications, prisms should be installed around drawpoint openings, fixed facilities areas, and at the crown, mid crown and ribs on the drift. These areas need to be monitored to record the convergence rate as the cave advances. If any displacement is recorded in these areas, it is essential that the ground support be re-evaluated and monitored.

Monitoring the subsidence zone with prisms is essential, as there will be correlations between the amount of surface subsidence and the draw rate within the cave. Surface subsidence can then be measured which will allow for a material mass balance to be calculated, which can then be used in model calibrations. A total station should be installed in an area where no movement is anticipated. The data for each prism is automatically collected for which the movement can then be calculated.

\subsection{Crackmeters}

Crackmeters are used to use for monitoring cracks that are forming within the shotcrete. When cracks are forming on the surface, this is an indication that there is an increase stress on the opening. There are two types of crackmeters, one that is manually read and the other is constructed with a vibrating wire element. The crackmeter must be installed over the forming crack or joint on either end. As the crack propagates, the crackmeter will accurately show the displacement. If the crackmeter being used is manually read, then the movement is observed with the position of the cross on the upper plate in respect to the grid. With an automated crackmeter, as tension is applied the vibrating wire element will experience strain which is directly proportional to the extension of the joint.

\subsection{LiDAR scanners}

LiDAR scanners are becoming increasingly popular in the mining industry. These scanners use remote sensing technology with lasers to collect measurements that can be used in 3D models. The data is collected as a 3D point cloud, and subsequent scans can be used to show surface change along the drift. It is important that scans are completed in regular intervals to capture displacement and to calculate the convergence rate.

\subsection{Interferometric synthetic aperture radar}

InSAR is a great tool to use for measuring subsidence due to block caving as it detects and measures displacement over time. InSAR specialists will compare multiple radar image pairs and create interferograms between to the images. The interferograms represent the difference in phase between the two images, and each pixel in the image is calculated. The displacement is calculated by taking the difference between the wavelength's phase over the acquisition dates. The results are then placed over satellite imagery so that specific locations of movement are shown. An example of subsidence viewed via InSAR is shown in Figure 5.

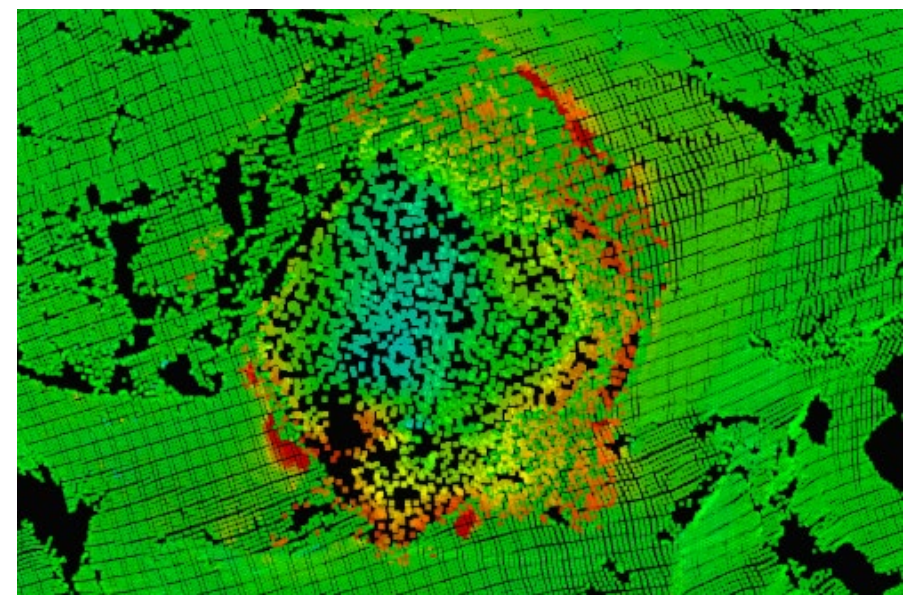

Figure 5 Subsidence occurring captured by InSAR satellites 


\section{$4 \quad$ Data analysis and representation}

Installing instrumentation is the first step in understanding the geohazards associated with block caving. The next step in the process is correlating the data and analysing the information to design a comprehensive risk management plan. A data acquisition and visualisation system should be implemented that can integrate the data collected, process the data, and provide useful tools for data visualisation. Figure 6 depicts a typical data flow from data collection to visualisation.

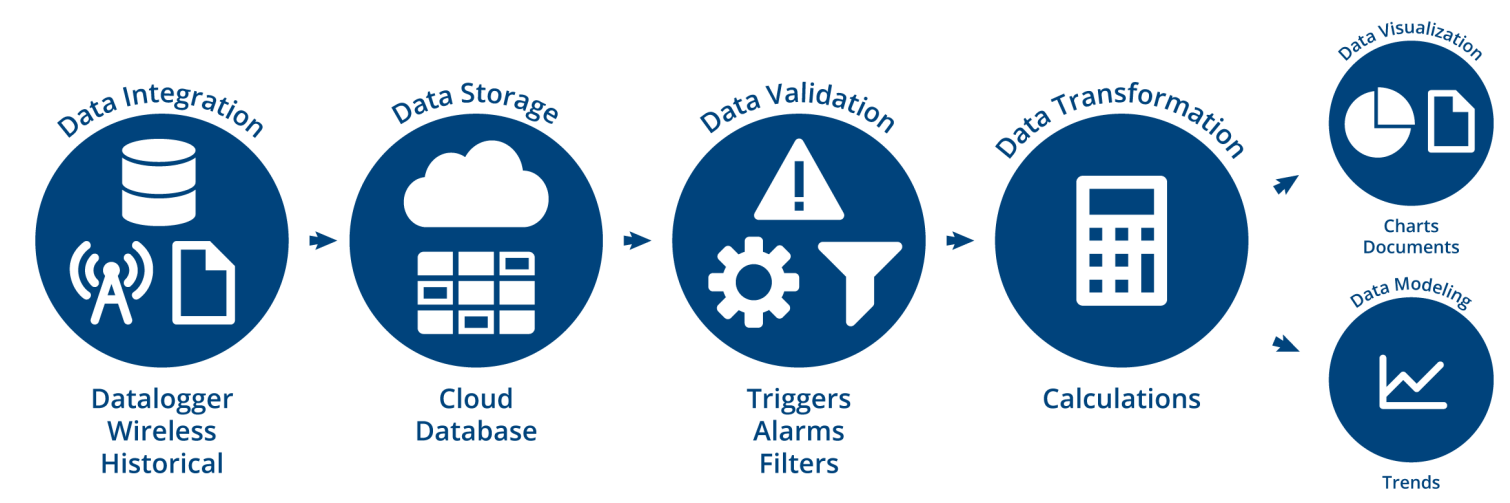

Figure 6 Data flow from collection to visualisation

\subsection{Data integration and processing}

Data can be imported either by direct connection to data loggers installed in the field, by SQL databases, or by manually collected data in CSV files. The frequency of the readings should be related to the activity in the area as well as to the rate at which ground conditions are changing. Too few of readings can cause important events to be missed which means that the appropriate actions were not taken. Too many readings due to unnecessarily rapid data collection can overload systems and introduce excessive latencies in data collection and processing.

It is also important that the data being integrated is checked for validity to provide an accurate management system. Instruments can have erroneous readings due to physical, environmental, and technical issues. If the instrument data is being collected manually, there is always room for human error. When data quality is poor, it can lead to improper data analysis and could lead to important events being missed.

After the data is in the management system, it is important that meaningful calculations are made that allow for the data to be analysed. It is important to note that each instrument type has its own set of calculations, and each calculation should be site based. The geotechnical engineers must be knowledgeable about the instrumentation and must use calculations that are in line with industry standards.

Once the calculations are in place, alarm thresholds need to be set that notify personnel of any calculated hazards are present. Each instrument should be set up with threshold alarms that are meaningful and give advanced warning to ensure personnel safety.

\subsection{Data visualisation and model calibration}

The final piece of geotechnical instrumentation monitoring is viewing the data in real time and correlating different instrument types. One way to do this is to make custom charts that integrate different instruments in the same area. These types of charts allow for quick representation of the data to which statistical analysis can be performed such as aggregate functions and trend lines. The data collected can then be used to calibrate stress models used for ground support design.

Another helpful way to correlate data is though GIS components which georeferences all the instrumentation in one comprehensive view. The use of contouring, heat maps, and vectors based on instrument data can also help geotechnical engineers with visualising trends. 


\section{Conclusion}

Geotechnical hazards associated with block caving such as mud rushes, convergence, induced seismicity, and subsidence must be monitored with instrumentation. By using a system that allows for the analysis of all data types, geotechnical engineers can make fast, real-time decisions that provide safe working environments for site personnel and can keep production running. It is important that both internal and external instrument types be used to create a comprehensive representation of ground conditions. In most cases, the internal instrumentation will be a key indicator of induced stress and movement and will be a first line of defence against potential failures. External instrumentation should be used to corroborate the information gathered from the internal instruments and should not be solely relied upon. By putting forth a comprehensive geotechnical instrumentation design, engineers can have insight into how the cave is reacting to undercutting and extraction as well as make sure the ground support design is functioning as expected.

\section{References}

Butcher, R, Stacey, T \& Joughin, W 2005, 'Mud rushes and methods of combating them', Journal of the South African Institute of Mining and Metallurgy, vol. 105, pp. 807-824.

Elexon Mining 2016a, Cave Tracker: Safe and Performing Block Cave Mines, brochure, viewed 8 April 2019, https://elexonmining.com/Brochures/Cave-Tracker-System.pdf

Elexon Mining 2016b, Networked Smart Markers - Wireless Cave Back Monitoring, brochure, viewed 8 April 2019, https://elexonmining.com/Brochures/Cave-Tracker-System.pdf

ESG Solutions 2019, Regional Seismicity, ESG Solutions, Kingston, viewed 29 June 2019, https://www.esgsolutions.com/mining-andgeotechnical/regional-seismicity

Geokon 2012, Model 4850 N.A.T.M. Style V.W. Concrete Stress Cells, fact sheet, viewed 8 April 2019, https://www.geokon.com/content/manuals/4850_Concrete_Stress_Cells_NATM_Style.pdf

Geokon 2018, Vibrating Wire Strain Gauges, fact sheet, viewed 8 April 2019, https://www.geokon.com/content/manuals/4200-42024204-4210_Strain_Gages.pdf

Geokon 2019a, Model 6150E MEMS Digital Addressable In-Place Inclinometer, fact sheet, viewed 8 April 2019, https://www.geokon.com/content/manuals/6150E_MEMS_RS485_Addressable_Digital_In-Place_Inclinometer.pdf

Geokon 2019b, Model 3200 Borehole Pressure Cell, fact sheet, viewed 8 April 2019, https://www.geokon.com/content/ manuals/3200_Hydraulic_Borehole_Pressure_Cell.pdf

Geokon 2019c, Model 4300 Series Vibrating Wire Stressmeter, fact sheet, viewed 8 April 2019, https://www.geokon.com/ content/manuals/4300EX-BX-NX_Stressmeters.pdf

Geokon 2019d, Model 4350BX Biaxial Stressmeter, fact sheet, viewed 8 April 2019, https://www.geokon.com/content/ manuals/4350BX_Biaxial_Stressmeter.pdf

Hudyma, M, Potvin, Y \& Allison, D 2008, 'Seismic monitoring of the Northparkes Lift 2 block cave - Part 2 production caving', Journal of the South African Institute of Mining and Metallurgy, vol. 108, pp. 421-430.

La Rosa, D \& Chen, D 1997, 'Development of the Automated Cave Monitoring System at Northparkes Mines', in H Gurgenci \& M Hood (eds), Proceedings of the 4th International Symposium on Mine Mechanisation and Automation, Colorado School of Mines, Golden, pp. 35-43.

Laubscher, D 2003, Cave Mining Handbook, De Beers, Johannesburg.

Measurand 2019, SAAV Manual, fact sheet, viewed 22 April 2019, http://saav.measurand.com/home

Mine Design Technologies 2019, SMART Cable Bolt, Mine Design Technologies, Kingston, viewed 8 April 2019, https://mdt.ca/products/instrumentation/smart-cable-bolt/

Mitri, H 2013, 'Evaluation of rock support performance through instrumentation and monitoring of bolt axial load', Proceedings of the 11th Underground Coal Operators' Conference, The Australasian Institute of Mining and Metallurgy, Melbourne, pp. 136-140.

Morton, K, Muresan, M \& Ramsden, E 2008, 'Importance of pore pressure monitoring in high walls', Journal of the South African Institute of Mining and Metallurgy, vol. 108, pp. 661-667.

Vallejos, J, Basaure, K, Palma, S \& Castro, R 2017, 'Methodology for evaluation of mud rush risk in block caving mining', Journal of the Southern African Institute of Mining and Metallurgy, vol. 117, pp. 1-7. 